\title{
ЗАСТОСУВАННЯ КЕЙС-МЕТОДУ У ФАХОВІЙ ПІДГОТОВЦІ СТУДЕНТІВ-ІНОЗЕМЦІВ НА КАФЕДРІ ТЕРАПЕВТИЧНОЇ СТОМАТОЛОГІї
}

М. О. Левків

\author{
ДВНЗ “Тернопільський державний медичний університет \\ імені І. Я. Горбачевського МОЗ Украӥни”
}

\section{APPLICATION OF CASE-METHOD STUDY IN THE PROFESSIONAL TRAINING OF FOREIGN STUDENTS AT THE DEPARTMENT OF THERAPEUTIC DENTISTRY}

\section{Horbachevsky Ternopil State Medical University}

\begin{abstract}
У статті наведено особливості викладання дисципліни за допомогою кейс-методу навчання, при якому роль викладача в цьому процесі посідає головне місце. Викладач мотивує навчальну діяльність студентів, спонукає їх до навчання, організовує навчальний процес таким чином, щоб він мав максимальний ефект. Готуючи практичне заняття з іноземними студентами, викладач повинен ретельно продумати структуру заняття, окреслити проблему та їі розв'язання, навчити студента творчо підходити до вивчення та засвоєння матеріалу, вміло користуватися набутими знаннями, а не лише надати студентові певний обсяг практичних навичок.
\end{abstract}

The article presents peculiarities of studying process using case-study method, in which the role of the teacher occupies a central place. Teacher motivates training activities of students, encourage them to study, organize the learning process so that it would have the maximum effect. Preparing practical classes with international students, the teacher should carefully consider the structure of the lessons, describe the problem and its solution, should train students to be creative in studying and learning process, train how to use acquired skills and knowledge correctly, not only providing students with a certain amount of practical skills.

Вступ. Досвід роботи з іноземними студентами показує, що цей контингент студентів потребує особливої тактики викладання. У першу чергу, це обумовлено тим, що дуже часто у групах навчаються студенти різних національностей, віросповідання, політичних поглядів. Всі ці студенти мають різну навчальну підготовку, бо навчалися за різними шкільними програмами. Це створює певні труднощі у викладанні дисципліни.

Оптимізація навчального процесу з іноземними студентами передбачає комплексний підхід до вирішення ряду проблем з метою покращення якості підготовки фахівців для різних країн.

У даний час уже неможливо обмежуватись лише такими вимогами до студентів, як компетентність у знаннях, уміннях і навичках. У всіх сферах стає затребуваним фахівець, який уміє працювати в команді, здатний генерувати ідеї та технологї̈ їх запровадження, має схильність до інновацій, уміє

() М. О. Левків критично, оперативно й аналітично працювати 3 величезними обсягами інформації різних видів.

Серед споконвічних проблем традиційного медичного навчання є певний розрив між теоретичними знаннями студентів і досвідом професійної діяльності. Синтез освіти, науки та інноваційної діяльності дозволяє розробляти та впроваджувати нові освітні технології світового рівня, формувати у випускників вищої школи професійні навики, забезпечувати їх конкурентну спроможність на міжнародному ринку медичних послуг.

Одним зі способів вирішення цього питання $є$ використання інтерактивних методів навчання в навчальному процесі студентів-стоматологів. Інтерактивне навчання - це навчання, заглиблене у процес спілкування. Організація інтерактивного навчання передбачає моделювання життєвих ситуацій, використання рольових ігор, спільне вирішення проблем на основі аналізу обставин і відповідної ситуації. 
Метою інтерактивного навчання є створення комфортних умов навчання, в яких кожний студентстоматолог відчуватиме свою успішність при вивченні стоматологічних дисциплін. Одним з інтерактивних методів є кейс-методика.

Метод case-study, або метод конкретних ситуацій (від англійського case - випадок, ситуація), - це метод активного проблемно-ситуаційного аналізу, оснований на навчанні шляхом вирішення конкретних завдань - ситуацій. Цей метод відноситься до неігрових імітаційних активних методів навчання й розглядається як інструмент, що дозволяє застосовувати теоретичні знання при вирішенні практичних завдань.

По суті, кейси - це інтегровані комплексні ситуаційні задачі. Якщо у клініці в конкретний момент відсутні пацієнти з патологією за темою заняття, зручно звертатись до кейсів.

Дану методику доцільно застосовувати наприкінці вивчення певного розділу зі студентами, які, маючи достатній рівень знань, можуть розвивати професійно-творче мислення.

Основна частина. При вивченні одного з найважливіших розділів терапевтичної стоматології“Захворювання СОПР” - ці навички набувають особливого значення, що пов’язано із доволі частим виникненням захворювань слизової. Незважаючи на те, що на кафедрі терапевтичної стоматології ТДМУ надається консультативно-лікувальна допомога таким хворим у повному обсязі, забезпечення навчального процесу тематичними хворими не завжди можливе. Крім того, пацієнти часто не бажають співпрацювати зі студентами. Вищенаведене зумовлює доцільність використання методу кейсу для вивчення цього розділу, що дозволяє розвинути і вдосконалити міждисциплінарну горизонтальну об’єктну інтеграцію, розуміння процесів розвитку захворювань слизової та їх ефективного комплексного лікування, які так необхідні для підготовки і становлення лікаря-стоматолога як спеціаліста.

Отже, метою нашого дослідження було випробування та впровадження в навчальний процес методу “case-study” на кафедрі терапевтичної стоматології ТДМУ і визначення його ефективності при вивченні розділу “Захворювання СОПР”.

Зокрема, акцентувалася увага на таких цілях: навчитися використовувати теоретичний матеріал для аналізу практичних проблем та формувати питання, розвинути системне інтегроване клінічне мислення, професійні клінічні навички, уміння різнобічно сприймати та вирішувати клінічну проблему.
Розділ “Захворювання СОПР” вивчається на V курсі і вимагає від студента глибоких знань із фундаментальних дисциплін: патологічної анатомії, патологічної фізіології, гістології, мікробіології, біохімії, фармакології, а також терапевтичних дисциплін: терапії, гастроентерології, кардіології, ендокринології тощо. Для комплексного сприйняття студентами етіопатогенезу, клінічних проявів хвороби та розуміння проблеми лікування хворих із захворюваннями СОПР така міждисциплінарна горизонтальна інтеграція вкрай необхідна. Для пошуку раціональних шляхів вирішення проблеми та засвоєння необхідних практичних умінь студентам пропонується за конкретною темою практичного заняття розібрати клінічну ситуацію, яка дозволяє використати набуті знання із суміжних навчальних дисциплін. В якості матеріалу для кейсів ми використовуємо фотографії клінічних проявів захворювання, до яких розробляються завдання або запитання.

Методика проведення практичного заняття

Студенти розподіляються на малі групи та діагностують, оцінюють і вибирають оптимальне вирішення клінічної ситуації. Викладач контролює їх роботу, допомагає, спрямовує їх дії у правильному напрямку, уникаючи прямих консультацій. У кожній малій групі студенти обирають доповідача, який презентує варіант вирішення клінічної ситуації, висловлюючи думку групи, після чого проводиться обговорення у формі відповідей на запитання, вирішення нетипових ситуаційних задач, підготовлених викладачем. Студентів спонукають знайти помилки, здійснити пошук необхідної інформації для їх виявлення і виправлення.

Під час спільного обговорення роль викладача $€$ прихованою, непомітною. У той же час викладач стежить за процесом обговорення:

- вчасно ставить запитання, які допоможуть студентам зробити крок уперед, і водночас оцінює значення ідей, запропонованих раніше;

- реалізує навички координатора діалогу та пов’язує виступи окремих студентів таким чином, щоб не тільки вони, а й уся група могла усвідомити їх значення;

- відчуває динаміку обговорення, має відчуття часу, яке підказує йому, що обговорення триває занадто повільно або занадто швидко, тому слід оптимізувати навчальний процес.

I тільки після спільного обговорення викладач повертається до традиційної ролі й підбиває підсумки заняття. 
На закінчення практичної частини заняття студенти намагаються вирішити основну проблемну ситуацію і сформулювати головні недоліки в діагностиці захворювань СОПР та верифікації діагнозу у хворих, їх лікуванні, обстеженні. Викладач оцінює знання і набуті вміння студентів, рівень доповідей, участь у їх обговоренні, запитання, вирішення проміжних і основних задач.

Для застосування кейс-методу у навчальному процесі викладач повинен виконати певні функції, а саме: проектувальну, конструктивну, організаційну, комунікативну і виховну. Це вимагає підвищення ефективності роботи самого викладача, який практикує ситуативний метод навчання, а також підвищення рівня якості навчального процесу, оскільки педагогічний потенціал кейс-методу навчання є значно більшим за обсягом і сучаснішим, ніж потенціал традиційних методів освіти. Цей метод передбачає, що викладач і студент повинні постійно взаємодіяти, вибираючи відповідні форми поведінки, і не лише під час практичних занять, але і на консультаціях.

Отже, застосування кейс-методу на практичних заняттях при вивченні терапевтичної стоматології дає змогу реалізувати такі сучасні дидактичні прийоми: індивідуальний підхід викладача до кожного студента в академічній групі зокрема; спонукання студента до роботи з інформацією; надання йому максимальної свободи в навчанні, не завантажуючи великим обсягом теоретичного матеріалу, а концентруючи увагу студента лише на основних положеннях теми практичного заняття; сприяння формуванню клінічних практичних навичок, оперативних професійних умінь тощо. Під час такого заняття викладач акцентує увагу на розвиток сильних граней студента як майбутнього лікарястоматолога.

Кейс-метод долає класичний стереотип традиційного навчання - “сухість” та “неемоційність” викладання навчального матеріалу і підвищує якість клінічної підготовки лікаря-стоматолога. Вищевикладене дозволяє рекомендувати кейс-метод для використання його на практичних заняттях кафедри терапевтичної стоматології та інших кафедр стоматологічного профілю.

У ситуаційному навчанні важливий не стільки кінцевий результат, скільки процес його знаходження, адже саме таким чином розвиваються професійні якості лікаря, який мислить. Крім того, використовуючи кейс-методику, слід виходити із припущення, що правильним може бути будь-яке рішення, якщо воно аргументоване. Тому викладач, підбиваючи підсумки, проводить аналіз не тільки самої ситуації, а й обговорення. Він обгрунтовує свою позицію щодо суті ситуації й водночас оцінює виступи представників творчих груп, тактовно визначає помилки, теоретичні “прогалини”, доводить необхідність вивчати теоретичні засади проблеми. Робота викладача перетворюється на “невидиму руку”, яка регулює процес аналізу конкретної ситуації, імпровізовано підтримуючи групу, котра ï потребує.

Активне навчання, зокрема кейс-метод, значно відрізняється від пасивного: застосовується примусова активація мислення, коли суб'єкт навчання змушений бути активним незалежно від бажання, оскільки їх активність повинна бути не короткочасною чи епізодичною, а у значному ступені стійкою і тривалою (протягом усього заняття); при активному навчанні стимулюються самостійне творче вироблення рішень, підвищення ступеня мотивації та емоційності слухачів. I, нарешті, найважливіше, те, що даний підхід спрямований за межі навчального простору, виходить у сферу професійних рішень проблем у конкретній галузі знань, формує інтерес і профільну мотивацію. Він розкриває перед майбутніми фахівцями-стоматологами можливості вивчити складні та професійно значущі питання в емоційно сприятливій атмосфері навчального процесу, використати набутий досвід у реальній практиці.

Отже, подальше впровадження інтерактивної методики навчання студентів із застосуванням “case-study” методу при викладанні розділу терапевтичної стоматології “Захворювання СОПР” $\epsilon$ перспективним.

Висновки: 1. Аналіз клінічних ситуацій вагомо впливає на професіоналізацію студентів, сприяє їх дорослішанню, формує інтерес і позитивну мотивацію на навчання та подальшу практичну діяльність.

2. При вирішенні кейса студенти-стоматологи не тільки використовують набуті теоретичні знання, а і проявляють свої особистісні якості, зокрема вміння працювати у групі, а також демонструвати рівень розуміння ситуації.

3. Кейс-метод дозволяє об'єктивно оцінити знання, практичні навички, професійні вміння студентів, розвиває клінічне мислення кожного окремого студента та його інтелектуальний потенціал.

4. Використання методу підвищує ефективність діяльності викладача кафедри та сприяє його професійному зростанню. 


\section{Список літератури}

1. Андюсев Б. Е. Кейс-метод как инструмент формирования компетентностей / Б. Е. Андюсев // Директор школи. - 2010. - № 4. - С. 61-69.

2. Богданова I. М. Використання інтерактивних технологій у підготовці майбутніх соціальних працівників / I. М. Богданова // Вісник Національної академії Державної прикордонної служби України. Педагогічні науки. - 2011. - № 11. - С. 15-20.

3. Ситуаційна методика навчання : теорія і практика / упор. О. Сидоренко, В. Чуба. - К. : Центр інновацій та розвитку, 2001.

4. Сурмін Ю. П. Метод аналізу ситуацій (Case study) та його навчальні можливості / Ю. П. Сурмін // Глобалізація і Болонський процес: проблеми і технології : кол. моногр. - К. : МАУП, 2005.

5. Максименко С. Д. Педагогіка вищої медичної освіти : підручник / С. Д. Максименко, М. М. Філоненко. - К. :
ТОВ “Видавництво “Центр навчальної літератури”, 2014. - 286 с.

6. Павельева Н. Кейс-метод в профессиональном образовании / Н. Павельева // Менеджмент знаний. 2008. - № 8. - С. 33-42.

7. Пометун О. І. Інтерактивні технології навчання: теорія, досвід : метод. посіб. / О. І. Пометун, Л. Пироженко. - К. : А.П.Н., 2002. - 136 с.

8. Савельева М. Г. Педагогические кейсы: конструирование и использование в процессе обучения и оценки компетентностей студентов / М. Г. Савельева. - Ижевск : Учебно-методическое пособие, 2013. - 94 с.

9. Сисоєва С. О. Інтерактивні технології навчання дорослих : навч.-метод. посіб. / С. О. Сисоєва ; НАПН України, Ін-т педагогічної освіти і освіти дорослих. К. : ВД “ЕКМО”, 2011. - 324 с. 